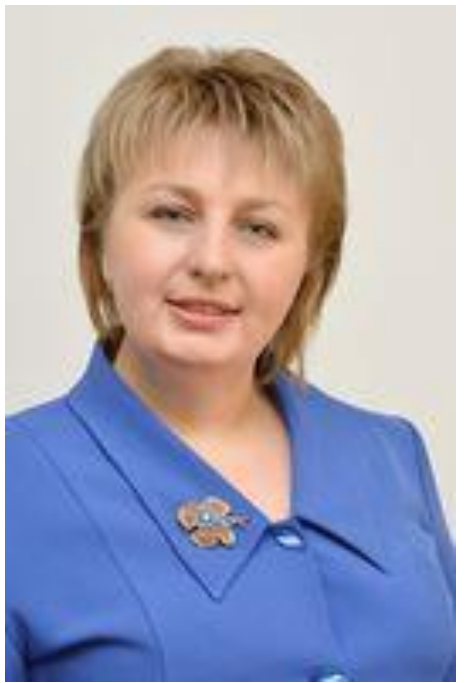

\title{
СТВОРЕННЯ КОМПЕТЕНТІСНО- ОРІЕНТОВАНОГО ОСВІТНЬОГО ПРОСТОРУ ЯК СТРАТЕГІЧНИЙ НАПРЯМОК РОЗВИТКУ ПЕДАГОГІЧНОГО ВИШУ
}

\author{
Ольга Набока \\ доктор педагогічних наук, професор, \\ перший проректор ДВНЗ «Донбаський державний \\ педагогічний університет», \\ м. Слов'янськ, Україна \\ ORCID ID 0000-0003-4635-0009 \\ olganaboka911@gmail.com
}

Анотація. У статті проаналізовано основні підходи до створення компетентнісноорієнтованого освітнього простору. Розкрито погляди науковців на розроблення компетентнісної парадигми підготовки майбутніх педагогів до професійної діяльності. Зауважено, що компетентісно-орієнтований освітній простір у закладах вищої педагогічної освіти є категорією, яка вміщує нормативно-правову, організаційну, інформаційну, навчальнометодичну, кадрову, мотиваційну, матеріально-технічну, фінансову складові. Доведено, що функціонування компетентнісно-орієнтованого освітнього простору в закладі вищої педагогічної освіти сприяє формуванню професійно-розвинутої особистості, підготовленої до відтворення та розвитку матеріальної та духовної культури суспільства, до гармонічного поєднання державних, суспільних, корпоративних й особистісних цілей і цінностей, здійснення ефективної професійної діяльності.

Ключові слова: заклад вищої освіти; підготовка педагога; компетентнісний підхід; освітній простір.

Постановка проблеми в загальному вигляді. Масштабність світових соціально-економічних змін, їхня складність, неоднозначність, суперечливість безперечно обумовлює зростання значущості системи вищої педагогічної освіти. Сучасні педагогічні виші розглядають свій подальший розвиток як рівноправних членів європейської освітньої спільноти, шляхом адаптації до вимог суспільства, конкурентної економіки через освітні пропозиції та якість освітніх послуг. Домінантним у сфері освіти стає підхід, що забезпечує не лише глибокими та різнобічними знаннями, а й здатностями скористуватись цими знаннями в ситуаціях різноманітних соціальних трансформацій. Основним інструментом досягнення цієї стратегічної перспективи $є$ створення компетентнісноорієнтованого освітнього простору в закладах вищої педагогічної освіти.

Аналіз останніх досліджень і публікацій. Розвиток педагогічної освіти та iii інтеграція в світовий освітній простір сприяє приєднанню України до 
євроінтеграційних процесів, зумовлює послідовність і змістовність трансформаційних змін у педагогічній освіті відповідно до сучасних цивілізаційних вимог. На цьому акцентували у своїх наукових працях розробники концептуальних та стратегічних засад розвитку вищої педагогічної освіти: Г. Балл, І. Бех, О. Біда, С. Гончаренко, М. Гриньова, О. Дубасенюк, І. Зязюн, А. Іванченко, В. Кремень, Н. Ничкало, В. Моляко, А. Реан, В. Рибалка, А. Сбруєва, С. Сисоєва, М. Солдатенков, М. Ярмаченко.

Формулювання цілей статті (постановка завдання). Метою статті $\epsilon$ аналіз основних підходів до створення компетентнісно-орієнтованого освітнього простору, розкриття поглядів науковців на розроблення компетентнісної парадигми підготовки майбутніх педагогів до професійної діяльності та визначення основних складових компетентнісно-орієнтованого освітнього простору в закладі вищої педагогічної освіти.

Результати дослідження. Реформування педагогічної освіти є важливим чинником формування високорозвиненої, моральної людської особистості, яка здатна не тільки користуватися значним обсягом інформації, а й породжувати нові знання, бути унікальним джерелом творчості та продуктивної суспільної діяльності. Стратегічним завданням закладів вищої педагогічної освіти стало створення у вишах компетентнісно-орієнтованого освітнього простору з такими основними характеристиками, як інноваційність, відповідність сучасному законодавчому та нормативному забезпеченню, наявність науково обгрунтованих критеріїв оцінювання якості освітнього процесу, відповідність державним стандартам освіти, урахування результатів моніторингу попиту та пропозицій потреби регіональних ринків праці в педагогічних кадрах.

Актуальність створення компетентнісно-орієнтованого освітнього простору $є$ реакцією педагогічної освіти на соціально-економічні явища та процеси. На думку вчених, наявні споживчі тенденції в суспільстві сприяють розмежуванню освіченості та навченості, що й формує відповідну освітню парадигму. Причиною цього є те, що консюмеристське суспільство потребує не освіченості, а професійної навченості, високого рівня професіоналізму у вишівській галузі, віртуозного володіння спеціальністю. У наш час величезна кількість спеціалістів виконує свої рутинні локальні функції в гігантській соціально-технічній машині, тоді як суспільству необхідні індивіди, що можуть повноцінно виражати свою суб'єктність у різноманітних формах: творенні, творчості, пізнанні. Це є освічені люди, без яких суспільство втрачає шанс на виживання (Ніколаєва, 2009). 
Ринкові відносини вимагають від сучасного працівника наявності компетенцій, які ще недостатньо враховані в освітньо-кваліфікаційних характеристиках освітньо-професійних програмах підготовки фахівців. Окремі фахові компетенції не пов'язані 3 тією чи тією дисципліною, мають надпредметний характер і відрізняються універсальністю. Такими базисними компетенціями до підготовки фахівців $є$ володіння «наскрізними» вміннями: робота на комп'ютері, користування базами та банками даних, знання й розуміння екології, економіки та бізнесу, філософські знання, комерційна кмітливість, уміння трансферу технологій, правові знання, уміння захисту інтелектуальної власності, знання нормативних умов функціонування підприємств різних форм власності, уміння презентації технологій і продукції, знання іноземних мов, знання принципів забезпечення безпеки життєдіяльності, знання принципів існування в умовах конкуренції та можливого безробіття, психологічна готовність до зміни професії і сфери діяльності тощо. Важливого значення набувають комунікативні навички та здібності, творчість, здатність до креативного мислення, здатність працювати в команді або самостійно, самосвідомість і самооцінка. Реалізація такої парадигми вимагає не лише перегляду змістовного наповнення навчальних дисциплін, а й організацію всього навчального процесу в спеціально створеному освітньому просторі.

На нашу думку, професійно-орієнтована підготовка повинна спрямовуватися насамперед на нове бачення цілей і оцінку результатів освіти, висувати свої вимоги до інших компонентів освітнього процесу: змісту, педагогічних технологій, засобів контролю й оцінки. У такому контексті головним $є$ проектування та реалізація компетентнісно-орієнтованого освітнього простору, який залучав студентів до різних видів діяльності (спілкування, вирішення проблем, дискусії, диспути, виконання проектів) і забезпечував формування у них значущих для їхньої майбутньої професійної діяльності якостей особистості, а також знань, навичок, умінь, що забезпечують ретельне виконання ними функціональних обов'язків.

Теоретичні передумови проектування та впровадження компетентнісноорієнтованого середовища пов'язано з його особливостями. В умовах нової парадигми «креативної освіти» недостатнім стає професійне навчання, орієнтоване на систему знань, умінь і навичок, співвіднесених тільки 3 функціональними обов'язками відповідної діяльності. Необхідним є насичення змісту професійного навчання широким спектром знань, що відображали б 
картину сучасної інформаційної сфери, характеризували б якість професійної діяльності, сприяли б системному оволодінню фахом.

Необхідно підкреслити, що останнім часом в академічному середовищі розвинених країн зростає невдоволення системою навчання, тому набуває поширення думка про недостатність використання окремих новітніх технологій. У цьому сенсі йдеться про поступове визрівання в надрах сучасної системи вищої освіти розуміння необхідності запровадження радикальних змін, які призвели б до трансформації всієї парадигми вищої освіти. Так, дослідники Р. Бар і Д. Таг сутність заміни однієї парадигми іншою розкривають крізь нове розуміння процесу навчання та місце навчального закладу, який повинен не стільки забезпечувати навчання, скільки виробляти його, використовуючи всі можливі засоби (Бар, б.д.). Ці парадигми відрізняються самою філософією освіти, місією та цілями вищих навчальних закладів, критеріями успіху, структурою навчання, теоретичними засадами, продуктивністю, особливостями діяльності викладача та студента.

Наголосимо, що нова місія вищої освіти полягає не в тому, щоб передавати знання від викладачів до студентів чи пропонувати програми та курси, а в тому, щоб створювати навчальну ситуацію, навчальне середовище, досягти того, щоб студенти відкривали та конструювали знання, дозволили різним групам студентів досягти успіху. Необхідно створювати сприятливі для студентів умови, за яких би вони «оволодівали функціональними структурами, що грунтуються на знаннях, а не обмежувалися короткотерміновими утриманнями в розумінні розрізнених, вирваних з контексту уривків інформації», щоб вони розуміли широкий контекст отриманих знань (Бар, б.д.).

Поняття освітнього простору $є$ важливою характеристикою освітнього процесу, який тісно пов'язаний не тільки з розвитком педагогічної науки, а й 3 іншими більш фундаментальними процесами, що відбуваються в суспільстві. Аналіз літератури свідчить про багатовимірність і різноплановість поняття «освітній простір». Так, під поняттям «освітній простір» розуміють певну територію, яка пов'язана з масштабними явищами в галузі освіти; певну частину соціального простору, у межах якої здійснюється нормована освітня діяльність; єдність, цілісне утворення в галузі освіти, яке має свої межі, що уточнюється окремо, - світовий освітній простір, міжнародний, європейський та освітній простір регіону, школи, вишу тощо. Найповнішим та сучасним, що концентрує в собі сутнісні ознаки цього феномена $\epsilon$, на нашу думку, визначення освітнього простору як «педагогічної реальності, яка заявляє про себе співіснуванням 
Людини i Світу через освіту, представляє собою баланс культурного i цивілізаційного, виражаючи його через знаковість освітнього середовища» (Леонова, 2006).

На думку сучасних освітніх експертів, найпершою вимогою до сучасного освітнього середовища $є$ доцільність, відповідність тій меті, що ставить суспільство перед освітнім закладом: усебічний розвиток самосвідомої особистості. Для освітнього простору це означає не лише функціональну придатність, доступність та безпечність території, приміщень та обладнання. Освітній простір має бути всеосяжний і цілісний, мати в основі єдину педагогічну, соціально-організаційну та художню концепцію. Розуміння простору як засобу освіти передбачає його сенсомоторну гетерогенність (різноманітність чуттєвих стимулів), семантичність (наповненість змістом), правдивість (відповідність форми та змісту), а також відкритість інтерпретації. Поєднання форм та кольорів в сучасному освітньому просторі скоріше запрошують до пошуку та дослідження, аніж пропонують (чи гірше нав'язують) готові відповіді, образи чи символи. Сучасний освітній простір $\epsilon$ індивідуалізованим та персоналізованим - створює неповторне враження, даючи водночас можливість кожному відшукати своє (Косенко, 2018).

Компетентнісно-орієнтований освітній простір у закладах вищої педагогічної освіти є більш широкою категорією та вміщує нормативно-правову, організаційну, інформаційну, навчально-методичну, кадрову, мотиваційну, матеріально-технічну, фінансову складові. Підкреслимо, що підгрунтям створення кожної із складових є наявність певних ресурсів.

Так, під нормативно-правовою складовою ми розуміємо накази, розпорядження, плани, графіки, розклади й інші нормативні та методичні документи, що регламентують перебіг процесу впровадження професійноорієнтованих технологій. Для визначення нормативно-правових ресурсів уважаємо за необхідне спочатку визначити всі питання освітнього процесу, які потребують нормативного та правового врегулювання. Наприклад, до них можуть належати питання нових умов атестації викладачів і студентів, прав студентів на вивчення певної частини предметів освітньої програми поза 3ВО тощо. Результатом визначення необхідних правових умов повинний стати перелік тих нормативних правових актів, які необхідно розробити для врегулювання освітнього процесу.

До організаційної складової віднесено органи, тобто посадові особи, постійні структурні підрозділи університету і факультету, постійні трудові 
колективи, тимчасові робітничі групи, їхні керівники, що забезпечують успішний хід освітнього процесу. Зауважимо, що процес створення компетентнісно-орієнтованого освітнього простору потребує наявності органів для виконання нових функцій, які конкретизовано в такий спосіб:

- координація й інтеграція діяльності предметних кафедр i їхніх фахівців, що утворюються на міжпредметній інтегративній основі;

- розроблення погоджених 3 іншими предметами за змістом i часом варіантів навчальних планів і реалізації програм навчальних курсів;

- організація розроблення професорсько-викладацьким складом навчально-методичних комплексів, що грунтуються на використанні компетентнісного підходу, а також програм стажувань і практик та інших форм самостійної роботи студентів;

- організація та надання психологічної та педагогічної підтримки студентам у процесі навчання згідно з індивідуальними навчальними планами;

- розроблення нового змісту, а також форм i методів проведення поточного та підсумкового контролю в контексті методології компетентнісноорієнтованого навчання.

Отже, важливо зазначити, що спочатку між уже чинними органами 3ВО рекомендовано розподілити ті нові функції, які схожі 3 колишніми. Так, наприклад, на навчально-методичний відділ ЗВО як основний координувальний орган можна покласти відповідальність за координацію й інтеграцію діяльності кафедр стосовно створення компетентнісно-орієнтованого освітнього простору. Цьому органу може бути також делегована функція організації розроблення нових навчально-методичних комплексів для навчання студентів і контролю за іхніми результатами навчання.

До наступної групи включено інформаційну складову, що вміщує інформаційну систему університету як сукупність умов, які забезпечують інформування всіх учасників компетентісно-орієнтованого освітнього простору. Елементами інформаційної системи є джерела інформації, користувачі, канали інформаційного зв'язку, ресурси, що забезпечують іiі функціонування; інформація, що забезпечує участь і погоджені дії всіх суб’єктів процесу: студентів професорсько-викладацького складу, ректорату, різних служб, соціальних партнерів університету та працедавців.

Для визначення інформаційної складової запропоновано розробити:

- максимально повний перелік усіх видів завдань, що виконують студенти, викладачі, управлінський персонал і служби університету, для 
виконання яких може бути необхідна інформація;

- визначити зміст інформаційних потоків зі врахуванням усіх груп користувачів;

- розробити вимоги до змісту та якості необхідної інформації, джерел і умов їі отримання;

- співвіднести необхідну систему інформації з тією, що існує, та виявити недоліки в інформаційному забезпеченні користувачів;

- розробити зміни наявної інформаційної системи університету та необхідних для цього умов.

На нашу думку, джерелами отримання інформації є навчально-методичні матеріали університету та інших 3ВО; освітні програми факультетів, вимоги до результатів згідно зі спеціальностями, що отримуються на факультетах, програми навчальних курсів, програми і списки літератури для самостійної роботи, тести для самоконтролю, навчально-методичні комплекси, нормативні документи з вищої освіти тощо.

Підкреслимо, що умовами якісної інформаційної підтримки процесу створення компетентнісно-орієнтованого освітнього простору є високий рівень вимог до якості інформації. Вона повинна бути своєчасною, повною, достовірною, відображати сутність питань і бути доступною користувачеві в зручному для роботи вигляді. Запропоновано розвинення каналів отримання такої інформації через:

- наявність можливості користуватися мережею Інтернет;

- наявність відповідних електронних каталогів літератури в бібліотеці;

- наявність бібліотечного фонду навчальної, наукової, довідкової, художньої та програмно-методичної літератури, ураховуючи роботи співробітників університету;

- наявність фондів літератури факультетів, лабораторій i наукових кафедр університету;

- наявність фонду комп'ютерних засобів навчання та контролю: підручників, відео- й аудіоматеріалів, комп'ютерних записів лекцій i дистанційних курсів для самостійної роботи, презентаційних матеріалів, довідників, тестових та інших програм для самоконтролю результатів навчання в університеті.

С очевидним, що питання інформаційного забезпечення організації навчального процесу $є$ менш важливим. Для його опрацювання вважаємо за доречне:

Професіоналізм педагога: теоретичні й методичні аспекти. - Вип. 10. - Слов'янськ, 2019. 
- наявність системи інформування про роботу університету, випускників загальноосвітніх шкіл й інших груп потенційних студентів університету;

- наявність інформаційної системи забезпечення взаємодії університету зі працедавцями з таких питань: участь працедавців у формуванні замовлення на якість вищої освіти, перелік вимог до професійних компетенцій випускників;

- участь працедавців у забезпеченні матеріально-технічних, організаційних, інформаційних, мотиваційних і фінансових умов для збільшення якості університетської освіти; задоволення потреб працедавців у кадрах з числа випускників ЗВО і наявності робочих місць на підприємствах і в організаціях працедавців;

- наявність комп'ютерної системи управління процесом розробки освітніх програм i складання розкладу навчальних занять студентів зі врахуванням їхнього навчання в умовах упровадження професійно-орієнтованих технологій;

- наявність комп'ютерної системи моніторингу, оцінки та контролю якості освіти студентів університету, доступної для ії потенційних користувачів;

- наявність інформаційної системи, що забезпечує можливість простежити становлення та розвиток професійної кар'єри випускників університету, аналіз безпосередніх і віддалених результатів якості освіти й інше.

Підкреслимо, що моніторинг відповідності професійної кваліфікації майбутніх педагогів вимогам ринку праці є складовою інформаційних умов. Традиційно системний моніторинг i контроль за процесом формування готовності майбутніх педагогів передбачає розроблення та застосування діагностичних методик для вивчення рівня сформованості готовності майбутніх педагогів до професійної діяльності; вивчення стану викладання спеціальних дисциплін 3 урахуванням вимог формування готовності до професійної діяльності; контроль успішності засвоєння системи знань, умінь i навичок майбутніми педагогами; моніторинг успішності проходження майбутніми педагогами виробничих практик тощо.

Водночас у процесі дослідження з'ясовано, що відповідність професійної підготовки вимогам ринку праці можлива за допомогою систематичного контролю згідно зі станом працевлаштування та подальшого продовження терміну трудової діяльності працевлаштованих випускників згідно з отриманою спеціальністю. Варто відзначити, що відповідно до чинних нормативноправових положень було затверджене Положення про підрозділ вищого 
навчального закладу щодо сприяння працевлаштуванню студентів і випускників, згідно з яким до функцій вищеозначеного підрозділу у ЗВО також належать:

- запровадження системи зворотного зв'язку між підприємствами, установами й організаціями (працедавцями) та вищим навчальним закладом для отримання об’єктивної оцінки якості фахової підготовки;

- здійснення моніторингу працевлаштування випускників і відстеження їхнього кар'єрного зростання.

Водночас варто зауважити, що механізм оцінки відповідності професійної кваліфікації випускників навчальних закладів потребам ринку праці через моніторинг професійної кар'єри випускників після закінчення ЗВО відсутній. У зв'язку 3 цим під час моніторингу працевлаштування випускників ми пропонуємо здійснювати оцінку їхньої конкурентоспроможності. Для цього доцільно враховувати ступінь відповідності теоретико-методичної підготовки та практичних навичок, отриманих випускниками 3ВО, потребам економіки (частина випускників, які не знайшли роботу після закінчення 3ВО; частина випускників, які не працевлаштувалися за спеціальністю). Необхідним $\epsilon$ здійснення об'єктивної оцінки результативності підготовки випускників: відповідність підготовки вимогам виробництва (тривалість зайнятості випускників на отриманому робочому місці; реалізація можливостей успішної службової кар'єри). Водночас важливо врахування суб'єктивної оцінки випускниками можливостей працевлаштування, трудового потенціалу, рівня знань і можливостей їхнього застосування.

Також важливим завданням $є$ розроблення механізму моніторингу працевлаштування випускників, складовою якого повинно виступати забезпечення координації дій навчальних закладів i працедавців щодо досягнення збалансованості інтересів у результативному працевлаштуванні випускників, налагодження тісніших зв’язків між ними, що дасть змогу суттєво підвищити якість підготовки спеціалістів i практичного навчання. Запропоновано форми такої координації через організацію зустрічей працедавців зі студентами та випускниками 3 питань можливості їхнього подальшого працевлаштування на конкретних підприємствах, в установах й організаціях, заходів щодо сприяння працевлаштуванню студентів і випускників (дні кар'єри, «круглі столи», семінари-практикуми, науково-практичні конференції, ярмарки вакансій, конкурси на заміщення вакантних посад за замовленням працедавця, проведення зустрічей iз кращими випускниками університету тощо). 
Отже, збільшується актуальність формування оперативних, достовірних і повних показників працевлаштування випускників, які можуть стати підгрунтям для виявлення та прогнозування кадрових потреб, формування переліку дефіцитних спеціальностей і компетенцій випускників, коректування освітніх програм. Ми запропонували використання базового інструментарію для здійснення моніторингу відповідності професійної кваліфікації майбутніх педагогів вимогам ринку праці, який містить анкети та форми спостереження, що заповнюють випускники, робітники ЗВО і підприємств, працедавці.

Розглянемо й навчально-методичну складову як систему науковометодичних заходів університету, що підтримує реалізацію програми, наявність навчально-методичних комплексів й інші методичних матеріалів, що забезпечують діяльність студентів i викладацького складу із створення компетентнісно-орієнтованого освітнього простору. Наголосимо, що реалізація цієї групи умов безпосередньо пов'язана 3 напрямами науково-дослідної діяльності викладачів. Так, до переліку напрямів досліджень рекомендовано включити ті, які будуть безпосередньо пов'язані з розробленням наукових i практичних питань реалізації в університеті компетентнісного підходу у фаховій підготовці майбутніх педагогів.

Удосконалення підходів до формування науково-методичного забезпечення професійно-орієнтованих технологій навчання запропоновано здійснювати через запровадження Навчально-методичного комплексу (НМК) як сукупності нормативних та навчально-методичних матеріалів у друкованій та електронній формах, необхідних і достатніх для ефективного виконання студентами навчальної програми навчальної дисципліни, передбаченої навчальним планом підготовки студентів відповідного освітньокваліфікаційного рівня за напрямом підготовки чи спеціальністю.

НМК повинен забезпечити всі основні етапи педагогічного процесу: повідомлення навчальної інформації та іiі сприймання, закріплення й удосконалення знань, умінь і навичок, їх застосування й контролю, та основних функцій освітнього процесу - освітньої, виховної та розвивальної. НМК розроблюються для всіх навчальних дисциплін відповідно до навчального плану.

Ефективність створення компетентнісно-орієнтованого освітнього простору, на нашу думку, можна забезпечити лише у випадку, коли здійснена робота 3 розроблення та проектування буде узагальнена та представлена у вигляді ще одного додаткового елемента науково-методичного забезпечення фахової підготовки майбутнього педагога - карти (паспорта) технології. На жаль, 
цей аспект діяльності викладача в сучасній педагогічній літературі висвітлено досить поверхово.

Ми приєднуємося до думки М. Віленського, який, зважаючи на те, що технологічна карта $є$ паспортом проекту майбутнього навчального процесу, у якому цілісно представлені головні його параметри, що забезпечують успіх навчання, розглядає іï як своєрідний інструментарій, який міг би зажадатися не лише автором-розробником, але й будь-яким іншим викладачем для організації ним дидактичного процесу в межах відповідної навчальної дисципліни. Учений наполягає на тому, що, у технологічній карті важливо відобразити основні моменти, що дозволяють педагогові представити всю цілісність спроектованої ним технології навчання.

Це означає, що в ній повинні бути зазначені цільові установки дисципліни (дидактичні цілі сформульовані в діагностичному вигляді); зміст навчального матеріалу, представлений як в модульній (кількість навчальних модулів), так і в структурній формі (матриці зв'язків, графи навчальної інформації, структурнологічні схеми, плани проведення конкретних навчальних занять); схеми управління пізнавальною діяльністю студентів; форми, методи та засоби навчання, що дозволяють їх реалізовувати; особливості використання на різних етапах навчання елементів дидактичного комплексу інформаційного забезпечення навчальної дисципліни; сукупність педагогічних завдань i комунікативних ситуацій, передбачених автором; систему оцінки, контролю та корекції навчального процесу (методи, види та форми контролю, педагогічні тести або тестові завдання).

Акцентуємо увагу, що ми згодні з таким підходом до формування структури карти технології, але вважаємо важливим цільові установки карти технологій сконцентрувати на формуванні професійної компетентності майбутніх педагогів (Віленський, 2010). Необхідним, на нашу думку, також є використання рангової сукупності карт із формування в майбутнього педагога окремих професійних компетенцій.

Деталізуємо кадрову складову, яка характеризуються складом i кваліфікацією педагогічних й управлінських кадрів, а також інших фахівців, що забезпечують створення компетентнісно-орієнтованого освітнього простору.

Під час дослідження виявлено, що в сучасному процесі навчання педагог $є$ носієм методу та методик обробки, перероблення й засвоєння навчальної інформації, а не джерелом цієї інформації (Щенников, Теслінов, Чернявська, 2006). Провідним видом діяльності сучасного педагога є діяльність методиста- 
організатора, технолога освітнього процесу. Він допомагає студентам використовувати раніше отримані знання як метод для вирішення проблемних ситуацій. Сучасний педагог на підставі аналізу виробничої технології має бути здатний спроектувати й управляти на практиці освітньою технологією. Потреба в науковій організації методичних знань виникла 3 появою професійної методичної творчості, розробленням та конструюванням складного методичного керівництва, різних технологій навчання. До сучасної діяльності викладача належать: опорні сигнали, листи робочих зошитів, структурно-логічні схеми, узагальнені алгоритми вирішення класу завдань, навчальні евристичні програми, освітні стандарти тощо.

Об’єктом діяльності є процес навчання, а предметом - процес створення методів, загальні закономірності конструювання регулятивних структур навчальної діяльності викладача. Конструювання складного методичного керівництва вимагає спеціальних наукових знань. Професіонал у сфері методичної діяльності займається проектуванням, розробленням та конструюванням освітніх систем, які, з одного боку, повинні задовольняти цілі та завдання, систему вимог суспільства та виробництва, а 3 іншого забезпечувати практику навчання комплексом спеціально розроблених, зв'язаних у єдину систему навчально-програмних засобів, методик і технологій навчання. Отже, від рівня сформованості методичної компетентності викладачів залежить планування, діагностика, організаційно-методична робота 3 розроблення та застосування професійно-орієнтованих технологій у фахову підготовку майбутніх педагогів.

3 огляду на сказане вище вважаємо, що тренінги-курси 3 підвищення професійної компетентності викладачів, майстер-класи викладачів спеціальних дисциплін, безперечно, сприятимуть зростанню рівня методичної компетентності педагогів. Ми пропонуємо до впровадження таку нетрадиційну форму підтримки методичної компетентності викладачів як віртуальний методичний кабінет, що являє собою:

- форму інтерактивного спілкування, у процесі якого можливо обмінятися інформацією, висловити свою думку, отримати консультацію 3 певного питання;

- можливість організувати методичний простір для викладачів, який створює оптимальний доступ до необхідної інформації в будь-який час;

- оперативну методичну допомогу молодим викладачам;

- можливість досвідченим викладачам брати активну участь у 
віртуальних педагогічних читаннях, ділитися досвідом.

Підкреслимо, що перехід до впровадження компетентнісно-орієнтованого освітнього простору, висуває абсолютно нові для більшості викладачів вимоги до їхньої взаємодії зі студентами ЗВО. Доцільним, на нашу думку, є переорієнтація позиції викладача на нові моделі поведінки. Ми пропонуємо взяти до розгляду та впровадження такі моделі.

Першою моделлю, яку розглянемо, буде модель «Педагог-консультант». Сутність пропонованої моделі полягає в тому, що відсутній традиційний виклад матеріалу викладачем, навчальна функція замінюється консультуванням, яке може здійснюватися як в реальному, так i в дистанційному режимі. Консультування зосереджене на розв'язанні конкретної проблеми. Передбачається, що консультант або вже знає розв'язання, яке він може запропонувати, або володіє способами діяльності, які вказують дорогу до вирішення проблеми. Основна мета в такій моделі навчання - навчити студента вчитися.

Другою моделлю $є$ модель «Педагог-модератор». Моделювання діяльність, спрямована на розкриття потенційних можливостей і здібностей тих, хто навчаються. Підгрунтям моделювання $\epsilon$ використання спеціальних технологій, що допомагають організувати процес вільної комунікації, обміну думками, що підводять студента до ухвалення рішення за рахунок реалізації внутрішніх можливостей. Моделювання націлене на розкриття внутрішнього потенціалу студента, на виявлення прихованих можливостей і нереалізованих умінь. Основними методами роботи педагога-модератора $є$ такі, які спонукають студентів до діяльності й активізують їх, виявляють їхні проблеми, організують дискусійний процес, створюють атмосферу товариської співпраці. Педагогмодератор виступає посередником, який встановлює стосунки між студентами.

Педагог-тьютор здійснює педагогічний супровід студентів. Діяльність педагога-тьютора, як і педагога-консультанта, спрямована не на відтворення інформації, а на роботу зі суб’єктним досвідом індивіда. Викладач аналізує пізнавальні інтереси, наміри, потреби, особисті прагнення кожного. Він розробляє спеціальні вправи та завдання, що спираються на сучасні комунікаційні методи, особисту та групову підтримку, продумує способи мотивації та варіанти фіксації досягнень, визначає спрямованість проектної діяльності. Спілкування 3 тьюторами може здійснюватися через тьюторіали, денні семінари, групи взаємодопомоги, комп'ютерні конференції. 


\section{О. НАБОКА \\ Створення компетентісно-орієнтованого освітнього простору \\ як стратегічний напрямок розвитку педагогічного вишу}

Завдання педагога-тьютора - допомогти студентам отримати максимальну віддачу від навчання, стежити за перебігом навчання, здійснювати зворотний зв'язок у процесі виконання завдань, проводити групові тьюторіали, консультувати студентів, підтримувати їхню зацікавленість у навчанні впродовж всього вивчення предмету, забезпечити можливість використання різних форм контакту з ним (особисті зустрічі, електронна пошта, комп'ютерні конференції). Підкреслимо, що описана зміна функцій викладача ЗВО є істотною і продукує такі ж зміни у вимогах до його підготовки. Наприклад, до нового переліку вимог до викладача вважаємо необхідним долучити обов'язкове володіння сучасними інформаційно-комунікаційними технологіями, а також орієнтацією в освітньому просторі університету та багато чого іншого.

У контексті дослідження не менш важливо розглянути мотиваційну складову, що розуміється як міра зацікавленості студентів, викладачів, фахівців, ректорату, соціальних партнерів університету й інших суб'єктів в успішній реалізації процесу створення компетентнісно-орієнтованого освітнього простору, готовність докладати зусилля для досягнення поставлених цілей.

На нашу думку, зміна парадигми вищої освіти продукує зовнішні та внутрішні стимули професорсько-викладацького складу до переходу на нові освітні парадигми. Зовнішні стимули актуалізуються приєднанням України до Болонської декларації та прагненням бути в руслі загальноєвропейського процесу з вироблення загального розуміння змісту кваліфікацій, структури ступенів й умов їхнього взаємного визнання. Внутрішні стимули визначаються незадоволенням викладачів результатами, що досягаються, порівняно зі зусиллями, які витрачаються ними на навчання студентів.

Визначення мотиваційних умов запропоновано починати 3 виявлення й оцінки мотивації суб'єктів як їхньої психологічної готовності до застосування професійно-орієнтованих технологій навчання. Зауважимо, що зміст мотиваційних умов передбачає наявність сприятливого для реалізації процесу впровадження професійно-орієнтованих технологій мотиваційного середовища, яке характеризується такими складовими:

- наявністю чітко поставлених цілей, які можуть бути засобом для оцінки їхньої діяльності;

- відповідністю поставлених цілей професійним інтересам i можливостям, що не буде перевантажувати при їхній реалізації;

- знанням кожним суб’єктом своєї ролі в реалізації програми;

- наявністю об'єктивної та справедливої системи контролю й оцінки 
діяльності співробітників університету з реалізації нових цілей;

- наявністю справедливої системи розподілу винагород.

3 іншого боку, необхідно виявити конкретні причини незацікавленості викладачів брати участь у процесі створення компетентнісно-орієнтованого освітнього простору та виконувати поставлені перед ними завдання. Так, можна чекати негативного ставлення викладачів до необхідності переробляти зміст програм і навчально-тематичних планів, розробляти нову систему оцінки та контролю, погоджувати свою діяльність 3 викладачами інших предметів, перебудовувати на новому підгрунті свою взаємодію зі студентами й інше, оскільки для цього необхідний час. Безумовно, методична робота з розроблення та впровадження професійно-орієнтованих технологій навчання у фахову підготовку майбутніх педагогів $є$ складною формою роботи викладача та потребує використання відповідних мотиваційних механізмів із боку адміністрації ЗВО.

Відзначимо, що об'єктивна й дієва система матеріального й морального заохочення викладачів до підвищення рівня наукової та методичної діяльності неодмінно сприятиме зростанню професіоналізму педагогів. Для мотивації найкращих індивідуальних досягнень викладача запропоновано використовувати:

- пріоритетне право на поширення (за рахунок 3ВО) свого педагогічного досвіду шляхом відвідування споріднених вищих навчальних закладів i публікації відповідних навчальних матеріалів у фахових виданнях;

- надання можливості стажування на провідних підприємствах України або за кордоном;

- матеріальне заохочення у формі доплати до основного окладу;

- пріоритетне право посідати вакантні посади викладачів відповідного рівня;

- представлення за поданням ректорату до відповідних відзнак державних органів влади та суспільних установ;

- зменшення (при відповідному збільшенні обсягу методичної роботи) навчального навантаження;

- пріоритетне право вступати в аспірантуру та докторантуру для здобуття наукового ступеня кандидатів і докторів наук тощо (Толочко, 2009).

Наступною групою умов ефективного створення компетентнісноорієнтованого освітнього простору є матеріально-технічна складова, до якої ми 
віднесли будівлі університету, навчальні й інші кабінети, навчально-наочне устаткування для ведення занять, технічні засоби навчання й інше.

Цілком ясно те, що процес створення компетентнісно-орієнтованого освітнього простору вимагає обов'язкового аналізу та проектування матеріально-технічного забезпечення в таких напрямах, як-от:

1) аудиторний фонд університету 3 урахуванням умов для реалізації предметно-діяльнісних модулів для проведення індивідуальних і групових занять студентів із викладачами; для самостійної роботи студентів під керівництвом викладачів;аудиторій, обладнаних для проведення тренінгів i використання інших активних методів навчання;лекційних аудиторій для роботи зі студентами; лабораторій для самостійної роботи студентів;

2) «мурали» та медіатеки 3 вай-фаєм, пандуси та інтерактивні дошки, мобільні робочі місця та енергоефективні фасади, лабораторне обладнання та «аудиторії без стін»;

3) навчально-наочне устаткування;

4) комп'ютерна база університету, його факультетів i бібліотеки: навчально-методичних комплексів, підручників, посібників, репетиторів i тренажерів; мультимедійних наочних засобів навчання, відеофільмів і відеофрагментів тощо.

Важливою вимогою ефективного створення компетентнісноорієнтованого освітнього простору, що висувається під час розроблення матеріально-технічної складової, $є$ запровадження в інфраструктурі навчального закладу навчально-тренувальних підрозділів. Основною метою таких підрозділів $\epsilon$ формування фахових знань і умінь студентів на підставі посилення їхньої практичної підготовки. Реалізація означеної мети навчально-тренувальних підрозділів пропонуємо через здійснення таких форм роботи:

- забезпечення реалізації системи тренінгів у навчальному процесі на грунті безперервного тренінгового процесу на всіх стадіях підготовки фахівців;

- організаційно-методичне забезпечення проведення тренінгових занять у межах віртуальних структур (закладів освіти);

- організація проходження студентами практики в межах віртуальних структур (закладів освіти);

- упровадження в процес викладання профільних дисциплін сучасних інноваційних технологій навчання;

- упровадження в процес викладання профільних дисциплін інформаційних технологій; 
- залучення до навчального процесу фахівців-практиків у сфері освіти;

- забезпечення функціонування віртуальних структур (закладів освіти);

- допомога студентам під час самостійної підготовки до участі в тренінгових заняттях;

- забезпечення можливості спілкування 3 колегами 3 університетів, науково-дослідних центрів, освітніх організацій усього світу;

- організація викладачами та студентами науково-пошукових досліджень і проектних розроблень відповідної проблематики;

- організація викладачами та студентами наукових і науково-методичних семінарів, ділових ігор, нарад, круглих столів, конференцій, симпозіумів;

- проведення відео-конференцій і дистанційних семінарів (вебінарів) для викладачів і студентів.

Безумовно, що підвищення ефективності діяльності таких навчальнотренінгових підрозділів можливе за умови використання сучасних інформаційно-комунікаційних технологій i мультимедійних засобів. Незважаючи на те, що в останні роки створено велику кількість мультимедійних засобів навчального призначення (різні енциклопедії, словники, довідники, презентації тощо), використання їх у навчальному процесі вищої школи епізодичне. Це пояснюється різними причинами, зокрема:

- недостатньою кількістю або відсутністю готових мультимедійних навчальних засобів, орієнтованих на конкретні зокрема й спеціальні дисципліни;

- недосконалістю професійно-орієнтованого програмного забезпечення навчального призначення;

- слабкою підготовкою викладачів спеціальних дисциплін у галузі інформаційно-комп'ютерних технологій, що не дозволяе їм самостійно розробляти або адаптувати вже розроблені засоби навчання, які грунтуються на мультимедійних технологіях до своїх лекційних або практичних занять;

- недостатнім рівнем матеріально-технічного оснащення та комп'ютерного забезпечення ЗВО.

На нашу думку, для розв'язання позначених проблем використання засобів інформаційно-комунікаційних технологій у межах діяльності навчальнотренінгових підрозділів доцільним є здійснення таких заходів:

- забезпечення навчально-виховного процесу необхідним технічним обладнанням, створенням та забезпеченням функціонування внутрішньої мережі Інтранету; 
- розроблення та впровадження електронних посібників, електронних навчально-методичних комплексів, що забезпечують формування професійних знань майбутніх фахівців згідно з принципами диференціації, індивідуалізації навчання;

- побудова навчального процесу зі застосуванням інноваційних технологій на базі інтегрованих методик через упровадження сучасних інформаційно-комунікаційних технологій (модульне, дистанційне навчання, мобільне навчання, e-learning, m-learning, blended learning, робота в Інтернеті тощо);

- розроблення та впровадження в навчально-виховний процес професійно-орієнтованих засобів інформаційно-комунікаційних і тренінгових технологій;

- організація системи підвищення кваліфікації викладачів у галузі інформаційно-комунікаційних технологій.

Підкреслюючи надзвичайну значущість визначених вище умов для застосування створення компетентнісно-орієнтованого освітнього простору, водночас зазначимо, що цей процес може стати неможливим через відсутність належних фінансових умов - наявність фінансових коштів. Щоб визначити об'єм фінансових ресурсів, необхідно врахувати витрати на всі види ресурсів щодо створення компетентнісно-орієнтованого освітнього простору (навчання, нова оплата праці викладачів, нові штатні одиниці в складі кафедр і факультету, створення нових кабінетів і лабораторій, закупівля комп'ютерного обладнання та програмного забезпечення тощо).

Висновки. Отже, запропоновані підходи до створення компетентнісноорієнтованого освітнього простору сприятимуть досягненню стратегічної мети цього процесу: формуванню професійно-розвинутої особистості, підготовленої до відтворення та розвитку матеріальної та духовної культури суспільства, до гармонічного поєднання державних, суспільних, корпоративних й особистісних цілей і цінностей. Перспективи подальших досліджень убачаємо в розробленні критеріїв і процедур моніторингу ефективності функціонування компетентнісноорієнтованого освітнього простору в закладах вищої педагогічної освіти.

\section{СПИСОК ВИКОРИСТАНИХ ДЖЕРЕЛ}

1. Бар, Р. Б. і Таг, Дж. От обучения кучению - новая парадигма высшего образования. Режим доступа: http://www.ffsn.bsu.by/ffsn.files/inform/el-libr/inf-com/01_Bar_Tag.pdf.

2. Виленский, М. Я., Образцов, П.И. і Уман, А.И. (2010). Технология профессионально-ориентированного обучения в высшей школе. Орел: ГОУ ВПО «ОГУ». 
Створення компетентісно-орієнтованого освітнього простору

як стратегічний напрямок розвитку педагогічного вишу

3. Косенко, Д. Новий освітній простір для нової украӥнськоӥ школи: місія нездійснена?! Режим доступа: http://education-ua.org/ua/articles/1115-novij-osvitnij-prostir-dlyanovoji-ukrajinskoji-shkoli-misiya-nezdijsnena

4. Леонова, О. (2006). Образовательное пространство как педагогическая реальность. Almaтаter(Вестник выстей школь), 1, 36 - 40.

5. Николаева, Е. М. і Щелкунов, М. Д. (2009). Образование в обществе потребления. Философия образования, 1 (26), 11 - 19.

6. Щенников, С. А., Теслинов, А. Г., Чернявская, А. Г. (2006). Основы деятельности тьютора в системе дистаниионного образования. Москва: Дрофа.

7. Ткаченко, Т. (2009). Організаційно-педагогічні умови формування професійної компетентності фахівців безпеки життєдіяльності засобами інформаційно-коммунікаційних технологій. Наукові записки. Сер.: Педагогіка, 3, $114-118$.

8. Толочко, С. В. (2009). Організаційно-педагогічні уомви формування методичної компетнтності викладачів вищих аграрних навчальних закладів. Науковий вісник Наи. ун-m біоресурсів та природокористування України, 143, 231 - 238.

\title{
DESIGNING COMPETENCY-BASED LEARNING ENVIRONMENT AS A STRATEGIC DIRECTION OF DEVELOPING TERTIARY PEDAGOGICAL INSTITUTION
}

\author{
Olha Naboka \\ Doctor of Pedagogical Sciences, Professor, \\ Vice-Rector of SHEI "Donbas State Pedagogical University" \\ Sloviansk, Ukraine \\ ORCID ID 0000-0003-4635-0009 \\ olganaboka911@gmail.com
}

\begin{abstract}
The article presents the main approaches to designing the competency-based approach of learning environment. The views of the scientists on developing the competency-based paradigm of preparing future educators for their professional activities are revealed. The author takes into consideration the scientific works of the scientists (H. Ball, I. Bekh, O. Bida, S. Honcharenko, V. Hryniova, O Dubaseniuk and others), devoted to the development of conceptual and strategic bases of higher education. The purpose of the article is to analyze the main approaches to designing the competency-based learning environment, to study the scientists' views on the problem of developing the paradigm of preparing the future educators for professional activities and to define the components of competency-based learning environment in tertiary pedagogical institutions.

The author emphasizes the relevance of developing the competency-based learning environment is a reaction of pedagogical education on the social and economic phenomena and processes. It is noted that competency-based learning environment in tertiary pedagogical institution is a category that includes the legal and regulatory, organizational, informational, learning and methodological, personnel, motivational, material and technical, and financial components. The effectiveness of developing the competency-based learning environment can be realized if the activities of designing and projecting is generalized and represented in the form of another additional element of scientific and methodological support of future educators' training - technology map (passport).

It is proved that the functioning of competency-based learning environment at tertiary pedagogical institution contributes to the formation of professionally developed personality, who is
\end{abstract}

Професіоналізм педагога: теоретичні й методичні аспекти. - Вип. 10. - Слов’янськ, 2019. 
ready for reproducing and developing the material and spiritual culture of the society, for harmonious unity of state, social, corporative, personal goals and values for conducting efficient professional activities.

Key words: tertiary institution; educator training; competency-based approach; learning environment.

\section{REFERENCES}

1. Bar, R. B. \& Tag, J. (n.d.). From learning to science - the new paradigm of higher education. Retrieved from //http://www.ffsn.bsu.by/ffsn.files/inform/el-libr/infcom/01_Bar_Tag.pdf.

2. Vilenskiy, M. Ya., Obraztsov, P. I., \& Uman, A. I. (2010). Technology of vocationaloriented training in higher education: textbook. Orel, the Russian Federation: GOU VPO "OGU".

3. Kosenko, D. A. (n.d.). New Learning Environment for New Ukrainian School: Mission Is Impossible?! Retrieved from http://education-ua.org/ua/articles/1115-novij-osvitnij-prostir-dlyanovoji-ukrajinskoji-shkoli-misiya-nezdijsnena.

4. Leonova, O. (2006). Educational Space as a Pedagogical Reality. Almamater (Vestnik vysshey shkoly), 1, 36-40.

5. Nikolaeva, E. M. \& Shchelkunov, M. D. (2009). Education in the Consumer Society. Filosofiya obrazovaniya, 1(26), 11-19.

6. Shchennikov, S. A., Teslinov, A. G., \& Chernyavskaya, A. G. (2006). Basics of the Tutor's Activity in the Distance Education System: Specialized Training Course. Moscow, the Russian Federation: Drofa.

7. Tkachenko, T. (2009). Organizational and Pedagogical Conditions of Development of Professional Competence of Specialists in Life Safety by Information and Communication Technologies. Naukovi zapysky. Seriia: Pedahohika, 3, 114-118.

8. Tolochko, S. V. (2009). Organizational and Pedagogical Development of the Methodological Competence of Teachers of Higher Agrarian Educational Institutions. Naukovyi visnyk Natsionalnoho universytetu bioresursiv ta pryrodokorystuvannia Ukrainy, 143, 231-238.

Матеріали надійшли до редакції 19.08.2019 р. 